\title{
In vitro Propagation of Globba schomburgkii Hook. f. via Bulbil Explants
}

\author{
Piyaporn SAENSOUK ${ }^{1,3}$, Surapon SAENSOUK ${ }^{1,2, *}$ and Phattaraporn PIMMUEN ${ }^{3}$ \\ ${ }^{1}$ Plant and Invertebrate Taxonomy and Its Applications Unit Group, Faculty of Science, \\ Mahasarakham University, Mahasarakham 44150, Thailand \\ ${ }^{2}$ Walai Rukhavej Botanical Research Institute, Mahasarakham University, Mahasarakham 44150, Thailand \\ ${ }^{3}$ Department of Biology, Faculty of Science, Mahasarakham University, Mahasarakham 44150, Thailand
}

('Corresponding author's e-mail: surapon.s@msu.ac.th)

Received: 29 January 2017, Revised: 17 September 2017, Accepted: 5 October 2017

\begin{abstract}
An efficient and rapid protocol for the micropropagation of Globba schomburgkii Hook. f. via bulbil explants was investigated. The long divided and undivided bubils of G. schomburgkii Hook. f. were cultured on MS medium (Murashige and Skoog) that had either $3 \mathrm{mg} / 1$ benzyladenine (BA) or 0.5 $\mathrm{mg} / \mathrm{l}$ naphthaleneacetic acid (NAA) added for 8 weeks. The results indicated that the long divided bulbils of G. schomburgkii Hook. f. showed a greater amount of plant regeneration than the undivided bulbils. Callus induction, as well as shoot and root formation, were observed when culturing microshoots of $1 \mathrm{~cm}$ in length on media (MS) that had Thidiazuron (TDZ) or NAA plus BA added at a range of concentrations for 8 weeks. The highest percentage of callus induction was $40 \%$ when culturing the microshoots on MS medium supplemented with NAA and BA. The best result for shoot formation was achieved when culturing the microshoots on MS medium with TDZ added. The highest number of roots was obtained when culturing the microshoots on MS medium with NAA and BA added. The in vitro-derived plantlets of $G$. schomburgkii Hook. f. were transplanted to pots containing different types of potting mixture in a greenhouse. The survival rates were $80 \%$ when G. schomburgkii Hook. f. was transplanted to sand.
\end{abstract}

Keywords: Globba schomburgkii Hook. f., propagation, callus induction, bulbil, acclimatization

\section{Introduction}

Globba schomburgkii Hook. f. is an attractive ornamental plant of the family Zingiberaceae and is found in Thailand. The center of diversity is found in continental monsoon Asia, where Thailand and neighboring countries are particularly rich in species. The plant is used as an ornamental plant. In Saraburi Province, Thailand, the flowers of Globba are bound together with candles during the Buddhist Lent. The genus Globba comprises 89 species worldwide, while there are 42 species of perennial rhizomatous herbs in Thailand that have uses as dyes, spices, or medicine. Another use of the species in Thailand is as cut flowers or ornamental plants, due to the inflorescences having yellowish bracts [1].

Under the conventional method, Globba species are propagated vegetatively by the underground rhizome, but this is disease susceptible and has a low propagation rate. The plants in the genus Globba are propagated using the underground rhizome, fruit, and bulbil. Considering the present demand (economic value) and propagation problem of the plant, it is necessary to develop a suitable protocol for mass propagation. The tissue culture technique is a suitable method of mass propagation. There are a few reports available that describe the Globba species' micropropagation, namely, Globba brachyanthera K. Schum. [2], G. sp. [3], Globba magnifica, G. winitii C.H. Wright, G. schomburkii cultivar "Burmese Dancing Girl" [4] and G. marantina L. [5].

In Zingiberaceae, different plant organs have been used as explants for tissue culture: rhizome [6], anther [7], leaves [8], leaf sheath [9], inflorescence bud [10], seeds [11], embryo [4], and bulbil [2]. Only 
http://wjst.wu.ac.th

some species of the genus Globba have bulbils, such as G. marantina L., G. flagellaris Larsen, and G. schomburgkii Hook. f. This paper reports the in vitro propagation of $G$. schomburgkii Hook. f. through bulbil explants. This study's objective was to develop, for the first time, and then present a fast in vitro system for the micropropagation of G. schomburgkii Hook. f., an attractive ornamental plant from Thailand, using the tissue culture technique.

\section{Materials and methods}

\section{Explant sources and sterilization}

Bulbils of G. schomburgkii Hook. f. (5 mm long) were collected from plants growing in Mahasarakham Province, Thailand (Figure 1). Running tap water was used to clean the bulbils for 30 min, before rinsing them using $70 \%(\mathrm{v} / \mathrm{v})$ ethyl alcohol for $30 \mathrm{~s}$, and sterilizing for $15 \mathrm{~s}$ with $15 \%$ sodium hypochlorite containing Tween 20 (2 drops), after which sterilized distilled water was used for 3 washes before culturing for 8 weeks on media (MS [12]) that was amended with either $3 \mathrm{mg} / 1 \mathrm{BA}$ or 0.5 $\mathrm{mg} / \mathrm{l}$ NAA.

\section{Medium and culture condition}

All experiments had $3 \%(\mathrm{w} / \mathrm{v})$ sucrose added to the $0.7 \%(\mathrm{w} / \mathrm{v})$ agar in the MS medium. Either $1 \mathrm{~N}$ $\mathrm{NaOH}$ or $1 \mathrm{~N} \mathrm{HCl}$ was used to ensure that the medium's $\mathrm{pH}$ was 5.8 before autoclaving for $15 \mathrm{~min}$ at 121 ${ }^{\circ} \mathrm{C}$. During the incubation of the cultures they were exposed to a $15 \mu \mathrm{mol} / \mathrm{m}^{2} / \mathrm{s} \mathrm{light} \mathrm{intensity} \mathrm{(white}$ fluorescent light) for a $16 \mathrm{~h}$ photoperiod at a temperature of $25 \pm 2{ }^{\circ} \mathrm{C}$. Observations on the percentage of callus induction, average number of shoots per explant, average number of roots per shoot, and average shoot and root length were recorded after 8 weeks of incubation.

\section{Acclimatization}

The in vitro regenerated plantlets $(7 \mathrm{~cm}$ long), which had both roots and shoots that were well developed, had the agar removed from the roots by washing with tap water and were transplanted to pots containing soil, sand, burned rice husk: soil:sand (1:1), soil:burned rice husk $(1: 1)$ and sand:burned rice husk (1:1), sand:burned rice husk (1:1), and soil:sand:burned rice husk (1:1:1). The potted plants were maintained under greenhouse conditions at Mahasarakham University, Thailand, in the Faculty of Science (Department of Biology), and were regularly irrigated with tap water.

\section{Statistical analysis}

The experiments were conducted using a completely randomized design (CRD) with 20 plantlets for each treatment. Each experiment was repeated 3 times. ANOVA tests were used to determine the results' significance, and the DMRT (Duncan's multiple range test) was used to observe the differences. All tests were considered significant at the $5 \%$ level, and were conducted using the SPSS program (version 11.5).

\section{Results and discussion}

The long divided and undivided bulbils of G. schomburgkii Hook. f. were used to evaluate the effects of explant type. After 8 weeks of culturing on the media (MS) that had either $3 \mathrm{mg} / 1 \mathrm{BA}$ or 0.5 $\mathrm{mg} / \mathrm{l}$ NAA added, the number of shoots (1.00 shoot/explant) and the number of roots (1.10 roots/explant) were found on the long divided bulbil (Table 1 and Figure 2). However, the undivided bulbils that were cultured on the media (MS) supplemented with $3 \mathrm{mg} / \mathrm{l} \mathrm{BA}$ or $0.5 \mathrm{mg} / 1 \mathrm{NAA}$ could not grow. This result indicated that the long divided bulbils of $G$. schomburgkii Hook. f., which was cultured with a $3 \mathrm{mg} / 1 \mathrm{BA}$ and $0.5 \mathrm{mg} / 1 \mathrm{NAA}$ supplementation of the media, resulted in the amount of shoot, root, and callus formation being significantly greater than when compared to that of the undivided bulbils. Kho et al. [2] presented work related to the propagation in vitro of G. brachyanthera K. Schum. by adventitious bulbils. Jala et al. [4] inoculated immature embryos of G. winitii C.H. Wright by trimming different parts of their seed coat. These results are similar to the observations of Pimmuen et al. [5] who cultured divided and undivided bulbils of G. marantina L. on MS medium and found that divided bulbils showed better growth 
http://wjst.wu.ac.th

than undivided bulbils. The results showed that the divided bulbils method could break dormancy because, when the bulbil was divided, it let water, oxygen, nutrients, and plant growth regulators pass though the bulbil to reach the micropyle directly. Chong et al. [13] also found that dividing the shoot explants of Curcuma zedoria Roscoe longitudinally into halves could enhance the formation of multiple shoots.

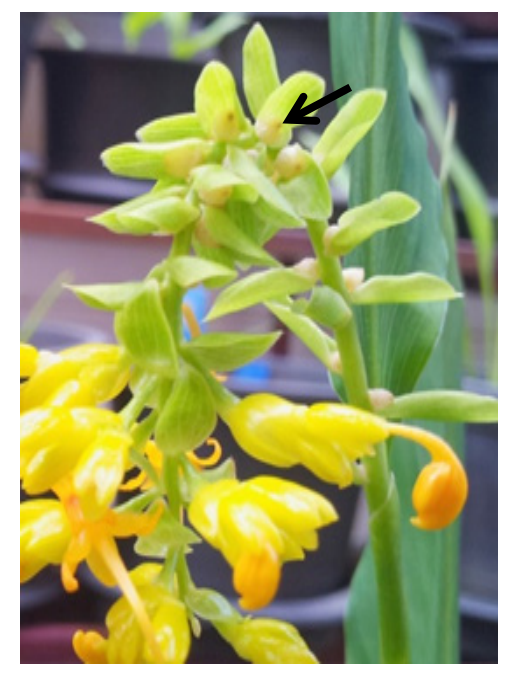

Figure 1 Bulbils of G. schomburgkii Hook. f. (arrow).

Table 1 Effect of explant incision on callus induction and shoot and root formation of G. schomburgkii Hook. f.

\begin{tabular}{lccccc}
\hline Explant type & $\begin{array}{c}\text { Percentage } \\
\text { of callus } \\
\text { induction }\end{array}$ & $\begin{array}{c}\text { Average no. of } \\
\text { shoots/explant } \\
\text { mean } \pm \text { SE }\end{array}$ & $\begin{array}{c}\text { Average shoot } \\
\text { length }(\mathbf{c m}) \\
\text { mean } \pm \text { SE }\end{array}$ & $\begin{array}{c}\text { Average no. of } \\
\text { roots/explant } \\
\text { mean } \pm \text { SE }\end{array}$ & $\begin{array}{c}\text { Average root } \\
\text { length }(\mathbf{c m}) \\
\text { mean } \pm \text { SE }\end{array}$ \\
\hline Divided bulbil & 50 & $1.0 \pm 0.44^{\mathrm{a}}$ & $0.54 \pm 0.22^{\mathrm{a}}$ & $1.10 \pm 0.72^{\mathrm{a}}$ & $0.70 \pm 0.22^{\mathrm{a}}$ \\
Undivided bulbil & 0 & $0 \pm 0.00^{\mathrm{b}}$ & $0 \pm 0.00^{\mathrm{b}}$ & $0 \pm 0.00^{\mathrm{b}}$ & $0 \pm 0.00^{\mathrm{b}}$ \\
\hline
\end{tabular}

*Means followed by the same letters within each column are not significantly different at $p \leq 0.05$, according to DMRT. 
http://wjst.wu.ac.th
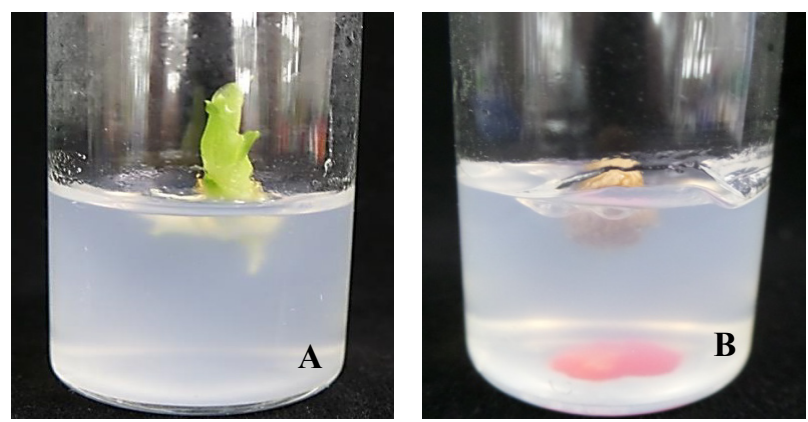

Figure 2 New shoot of G. schomburgkii Hook. f. germinated from bulbil after 8 weeks of culture. (A) Divided bulbil, (B) undivided bulbil.

Callus formation occurred at the shoot base of the microshoot when the MS medium had TDZ (0.1, 0.5 or $1 \mathrm{mg} / \mathrm{l}$ ) added. The callus was soft in texture, friable in structure, and yellowish white. When there was no growth regulator added to the medium, there were no calluses formed. The highest percentage of callus formation $(30 \%)$ came from the microshoots being cultured on a media for 8 weeks that had 0.1 $\mathrm{mg} / \mathrm{l} \mathrm{TDZ}$ added (Table 2 and Figure 3). When considering the multiplication of the shoots, TDZ (0.1 - 2 $\mathrm{mg} / \mathrm{l})$ produced $6.30-9.10$ shoots/explant. Srirat et al. [14] reported that the suitable conditions for shoot propagation of Curcuma longa L. were obtained when sucrose $(60 \mathrm{~g} / \mathrm{l})$ and TDZ $(5 \mathrm{mg} / \mathrm{l})$ were part of the media. Lo-apirukkul et al. [15] found that, when the terminal bud explants were cultured, they could obtain the greatest rate for the shoot multiplication (11.82 shoots/explant) for Curcuma comosa Roxb. on MS media that was semi-solid with the addition of TDZ $(18.16 \mu \mathrm{M})$. Hamirah et al. [16] also reported that TDZ at $0.5 \mathrm{mg} / \mathrm{l}$ was found to induce the highest shoot multiplication of Zingiber montanum Koenig. with a mean of 8.1 shoots/explant. These studies are similar to that of Zhang et al. [17], in which it was found that, when TDZ was added to the growing medium of Curcuma soloensis Valeton., it resulted in over 3 times the number of shoots as BA (18.7 or 5.0 shoots/explant from media, with $2.5 \mu \mathrm{M}$ TDZ or 40 $\mu \mathrm{M}$ BA, respectively). Higher concentrations of TDZ had no inhibitory effects on shoot multiplication but decreased the callus formation percentage. At a low concentration of, or without, TDZ in the culture media, numerous lengths of shoots and roots, as well as the number of roots, were produced. These results agree with those of Pimmuen et al. [5] that TDZ is suitable for shoot multiplication of G. marantina L.

Table 2 Effects of TDZ on callus induction and shoot and root formation of G. schomburgkii Hook. f.

\begin{tabular}{lccccc}
\hline $\begin{array}{c}\text { TDZ } \\
(\mathbf{m g} / \mathbf{l})\end{array}$ & $\begin{array}{c}\text { Percentage of } \\
\text { callus } \\
\text { induction }\end{array}$ & $\begin{array}{c}\text { Average no. of } \\
\text { shoots/explant } \\
\text { mean } \pm \text { SE }\end{array}$ & $\begin{array}{c}\text { Average shoot } \\
\text { length }(\mathbf{c m}) \\
\text { mean } \pm \text { SE }\end{array}$ & $\begin{array}{c}\text { Average no. of } \\
\text { roots/explant } \\
\text { mean } \pm \text { SE }\end{array}$ & $\begin{array}{c}\text { Average root } \\
\text { length (cm) } \\
\text { mean } \pm \text { SE }\end{array}$ \\
\hline 0 & 0 & $1.50 \pm 0.16^{\mathrm{b}}$ & $5.89 \pm 0.43^{\mathrm{b}}$ & $6.40 \pm 0.66^{\mathrm{b}}$ & $2.36 \pm 0.22^{\mathrm{a}}$ \\
0.1 & 30 & $6.30 \pm 1.36^{\mathrm{a}}$ & $2.34 \pm 0.18^{\mathrm{a}}$ & $8.60 \pm 2.07^{\mathrm{a}}$ & $1.45 \pm 0.08^{\mathrm{b}}$ \\
0.25 & 0 & $8.30 \pm 1.01^{\mathrm{a}}$ & $1.70 \pm 0.09^{\mathrm{a}}$ & $6.30 \pm 1.28^{\mathrm{b}}$ & $1.07 \pm 0.07^{\mathrm{c}}$ \\
0.5 & 20 & $7.00 \pm 0.80^{\mathrm{a}}$ & $2.03 \pm 0.12^{\mathrm{a}}$ & $3.90 \pm 0.79^{\mathrm{b}}$ & $0.71 \pm 0.06^{\mathrm{d}}$ \\
1 & 20 & $9.10 \pm 1.12^{\mathrm{a}}$ & $1.94 \pm 0.06^{\mathrm{a}}$ & $2.29 \pm 0.56^{\mathrm{b}}$ & $0.65 \pm 0.05^{\mathrm{d}}$ \\
2 & 0 & $9.10 \pm 1.37^{\mathrm{a}}$ & $2.02 \pm 0.05^{\mathrm{a}}$ & $2.90 \pm 0.76^{\mathrm{b}}$ & $0.63 \pm 0.09^{\mathrm{d}}$ \\
\hline
\end{tabular}

* Means followed by the same letters within each column are not significantly different at $p \leq 0.05$, according to DMRT. 

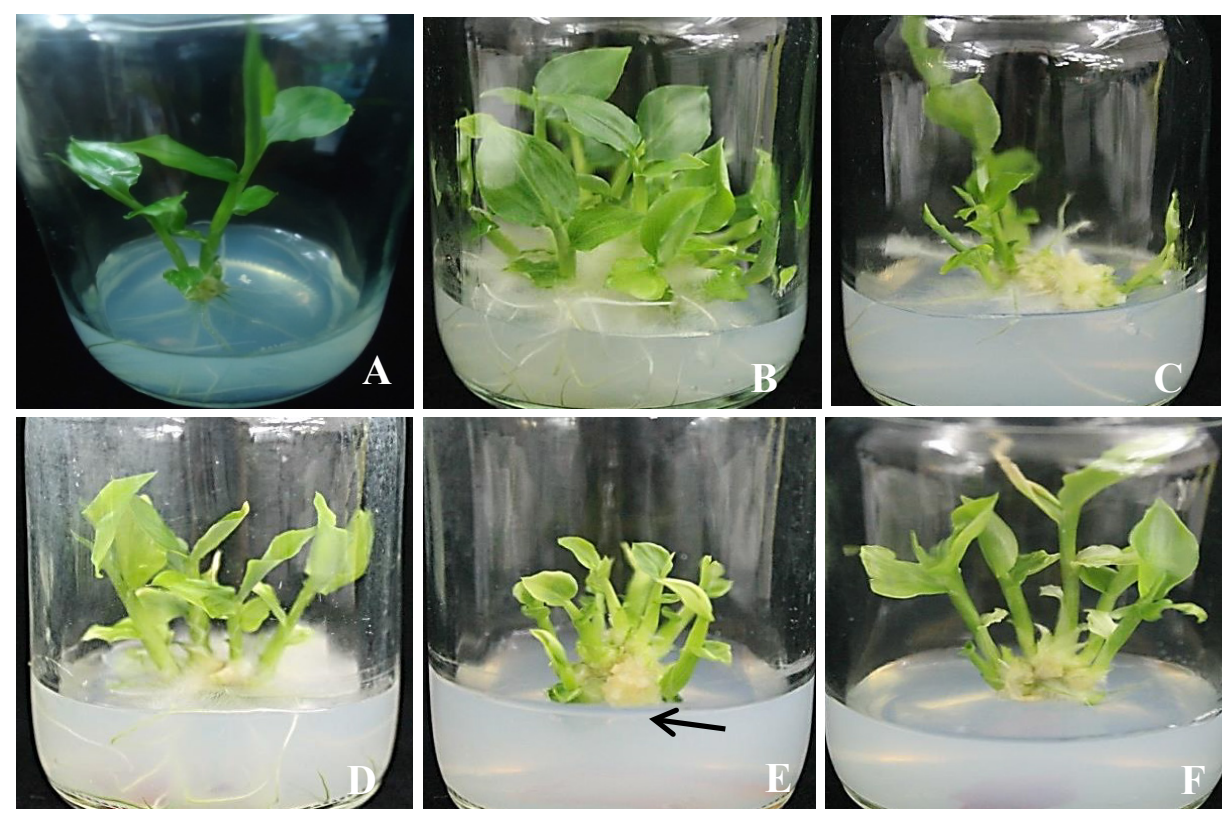

Figure 3 Multiple shoot formation and callus induction of $G$. schomburgkii Hook. f. after 8 weeks of culture on MS medium with various concentrations of TDZ added. (A) $0 \mathrm{mg} / \mathrm{l}$, (B) $0.1 \mathrm{mg} / 1$, (C) 0.25 $\mathrm{mg} / \mathrm{l}$, (D) $0.5 \mathrm{mg} / \mathrm{l}$, (E) $1 \mathrm{mg} / \mathrm{l}$, (F) $2 \mathrm{mg} / \mathrm{l}$ (callus indicated with arrow).

Callus formation occurred at the shoot base of the microshoot when cultured on the media (MS) with either $4 \mathrm{mg} / \mathrm{l} \mathrm{BA}$ or $0.5 \mathrm{mg} / 1 \mathrm{NAA}$ with $3 \mathrm{mg} / \mathrm{l} \mathrm{BA}$, as well as $1 \mathrm{mg} / \mathrm{l} \mathrm{NAA}$ with $0.5 \mathrm{mg} / 1 \mathrm{BA}$ added. The callus was soft in texture, friable in structure, and yellowish white. The highest percentage of callus formation $(40 \%)$ was obtained from microshoots that came from the media that had $0.5 \mathrm{mg} / 1 \mathrm{NAA}$ plus 3 $\mathrm{mg} / \mathrm{l} \mathrm{BA}$ added, which was more effective than the addition of TDZ at $0.1 \mathrm{mg} / 1$ that resulted in a callus induction of $30 \%$. In this study, the microshoots were cultured on MS medium supplemented with NAA and BA; the shoots were taller than the microshoots that were cultured on the medium added with TDZ. However, the average number of shoots was lower than the microshoots when cultured on media added with TDZ. These results are in agreement with those of Kho et al. [2], who reported in vitro propagation of Globba brachyanthera K. Schum. on MS medium supplemented with NAA and BA. The best response for the number of shoots per explant (5.4 shoots/explant) was obtained on MS medium supplemented with $3 \mathrm{mg} / \mathrm{l} \mathrm{BA}$ and $0.5 \mathrm{mg} / 1 \mathrm{NAA}$ for 8 weeks. There is only one report from Jala et al. [4], who studied embryos of $G$. schomburgkii Hook. f. cultured on MS medium supplemented with $5 \mathrm{mg} / \mathrm{l} \mathrm{BA}$ for 8 weeks, producing new shoots at 5.33 shoots/explant. Rahman et al. [18] also reported that $0.1 \mathrm{mg} / \mathrm{l} \mathrm{NAA}$ and 1.0 $\mathrm{mg} / \mathrm{l} \mathrm{BA}$ showed the highest number of shoots per culture from Kaempferia galanga L. rhizome tip and lateral bud explants of the field grown plant. Kambaska et al. [19] found that NAA and BA induced shoot formation in rhizome sprouting of Zingiber officinale Rosc. Zhang et al. [20] reported that NAA and BA could be used for callus induction of Curcuma kwangsiensis Lindl. for root formation. The microshoots of G. schomburgkii Hook. f. cultured on NAA and BA, produced 13.60 - 24.30 roots/explant; however, the microshoots cultured on TDZ produced 2.29 - 18.60 roots/explant (Tables 2 and $\mathbf{3}$ and Figures 3 and 4). 
http://wjst.wu.ac.th

Table 3 Effects of NAA and BA on callus induction and shoot and root formation of G. schomburgkii Hook. f.

\begin{tabular}{|c|c|c|c|c|c|c|}
\hline $\begin{array}{c}\text { NAA } \\
(\mathrm{mg} / \mathrm{l})\end{array}$ & $\underset{(\mathrm{mg} / \mathrm{l})}{\mathrm{BA}}$ & $\begin{array}{l}\text { Percentage } \\
\text { of callus } \\
\text { induction }\end{array}$ & $\begin{array}{c}\text { Average no. of } \\
\text { shoots/explant } \\
\text { mean } \pm \text { SE }\end{array}$ & $\begin{array}{c}\text { Average shoot } \\
\text { length }(\mathbf{c m}) \\
\text { mean } \pm \text { SE }\end{array}$ & $\begin{array}{c}\text { Average no. of } \\
\text { roots/explant } \\
\text { mean } \pm \text { SE }\end{array}$ & $\begin{array}{c}\text { Average root } \\
\text { length }(\mathrm{cm}) \\
\text { mean } \pm \text { SE }\end{array}$ \\
\hline 0 & 0 & 0 & $2.40 \pm 0.63^{\mathrm{ab}}$ & $6.32 \pm 0.35^{\mathrm{a}}$ & $7.90 \pm 1.11^{\mathrm{h}}$ & $2.94 \pm 0.12^{\mathrm{a}}$ \\
\hline 0 & 0.5 & 0 & $2.20 \pm 0.44^{\mathrm{ab}}$ & $4.06 \pm 0.44^{\mathrm{bcd}}$ & $11.80 \pm 1.43^{\mathrm{fgh}}$ & $1.78 \pm 0.09^{\mathrm{bcd}}$ \\
\hline 0 & 1 & 0 & $2.20 \pm 0.64^{\mathrm{ab}}$ & $3.80 \pm 0.57^{\mathrm{fg}}$ & $11.50 \pm 1.99^{\mathrm{fgh}}$ & $1.26 \pm 0.17^{\mathrm{f}}$ \\
\hline 0 & 2 & 0 & $3.00 \pm 0.57^{\mathrm{ab}}$ & $4.01 \pm 0.29^{\mathrm{efg}}$ & $14.80 \pm 2.36^{\operatorname{defg}}$ & $1.43 \pm 0.08^{\mathrm{def}}$ \\
\hline 0 & 3 & 0 & $3.80 \pm 0.80^{\mathrm{a}}$ & $3.72 \pm 0.38^{\mathrm{fg}}$ & $16.00 \pm 2.38^{\text {bcdef }}$ & $1.40 \pm 0.04^{\mathrm{def}}$ \\
\hline 0 & 4 & 10 & $3.30 \pm 0.95^{\mathrm{ab}}$ & $3.31 \pm 0.49^{\mathrm{g}}$ & $15.40 \pm 3.24^{\mathrm{defg}}$ & $1.34 \pm 0.16^{\mathrm{ef}}$ \\
\hline 0.5 & 0 & 0 & $2.40 \pm 0.42^{\mathrm{ab}}$ & $4.65 \pm 0.67^{\text {cdefg }}$ & $13.40 \pm 2.31^{\mathrm{defg}}$ & $1.54 \pm 0.19^{\text {cdef }}$ \\
\hline 0.5 & 0.5 & 0 & $1.90 \pm 0.40^{\mathrm{b}}$ & $5.43 \pm 0.38^{\mathrm{abcd}}$ & $13.60 \pm 1.10^{\text {degh }}$ & $2.02 \pm 0.12^{\mathrm{b}}$ \\
\hline 0.5 & 1 & 0 & $2.60 \pm 0.37^{\mathrm{ab}}$ & $5.24 \pm 0.13^{\text {abcde }}$ & $14.20 \pm 1.30^{\operatorname{defg}}$ & $1.68 \pm 0.11^{\text {bcde }}$ \\
\hline 0.5 & 2 & 0 & $2.20 \pm 0.32^{\mathrm{ab}}$ & $5.72 \pm 0.37^{\mathrm{abc}}$ & $14.10 \pm 1.34^{\mathrm{defg}}$ & $1.69 \pm 0.08^{\text {bcde }}$ \\
\hline 0.5 & 3 & 40 & $2.40 \pm 0.65^{\mathrm{ab}}$ & $5.40 \pm 0.46^{\mathrm{abcd}}$ & $13.90 \pm 0.80^{\text {defg }}$ & $2.05 \pm 0.12^{\mathrm{b}}$ \\
\hline 0.5 & 4 & 0 & $2.70 \pm 0.33^{\mathrm{ab}}$ & $5.06 \pm 0.47^{\mathrm{abcdef}}$ & $15.50 \pm 2.36^{\operatorname{defg}}$ & $1.85 \pm 0.09^{\mathrm{bc}}$ \\
\hline 1 & 0 & 0 & $2.10 \pm 0.40^{\mathrm{ab}}$ & $5.25 \pm 0.48^{\text {abcde }}$ & $21.40 \pm 1.71^{\mathrm{ab}}$ & $1.68 \pm 0.09^{\text {bcde }}$ \\
\hline 1 & 0.5 & 20 & $2.80 \pm 0.51^{\mathrm{ab}}$ & $4.84 \pm 0.37^{\text {bcdef }}$ & $18.80 \pm 1.72^{\mathrm{abcd}}$ & $1.71 \pm 0.07^{\mathrm{bcd}}$ \\
\hline 1 & 1 & 0 & $2.90 \pm 0.37^{\mathrm{ab}}$ & $5.63 \pm 0.30^{\mathrm{abc}}$ & $19.80 \pm 1.52^{\mathrm{abcd}}$ & $1.73 \pm 0.12^{\mathrm{bcd}}$ \\
\hline 1 & 2 & 0 & $2.60 \pm 0.45^{\mathrm{ab}}$ & $6.14 \pm 0.25^{\mathrm{ab}}$ & $16.20 \pm 1.59^{\text {bcdef }}$ & $1.84 \pm 0.07^{\mathrm{bc}}$ \\
\hline 1 & 3 & 0 & $3.50 \pm 0.47^{\mathrm{ab}}$ & $5.41 \pm 0.42^{\mathrm{abcd}}$ & $24.30 \pm 1.69^{\mathrm{a}}$ & $1.68 \pm 0.07^{\mathrm{bcde}}$ \\
\hline 1 & 4 & 0 & $2.90 \pm 0.37^{\mathrm{ab}}$ & $6.01 \pm 0.33^{\mathrm{abc}}$ & $20.80 \pm 2.15^{\mathrm{abc}}$ & $1.94 \pm 0.08^{\mathrm{b}}$ \\
\hline
\end{tabular}

* Means followed by the same letters within each column are not significantly different at $p \leq 0.05$, according to DMRT. 

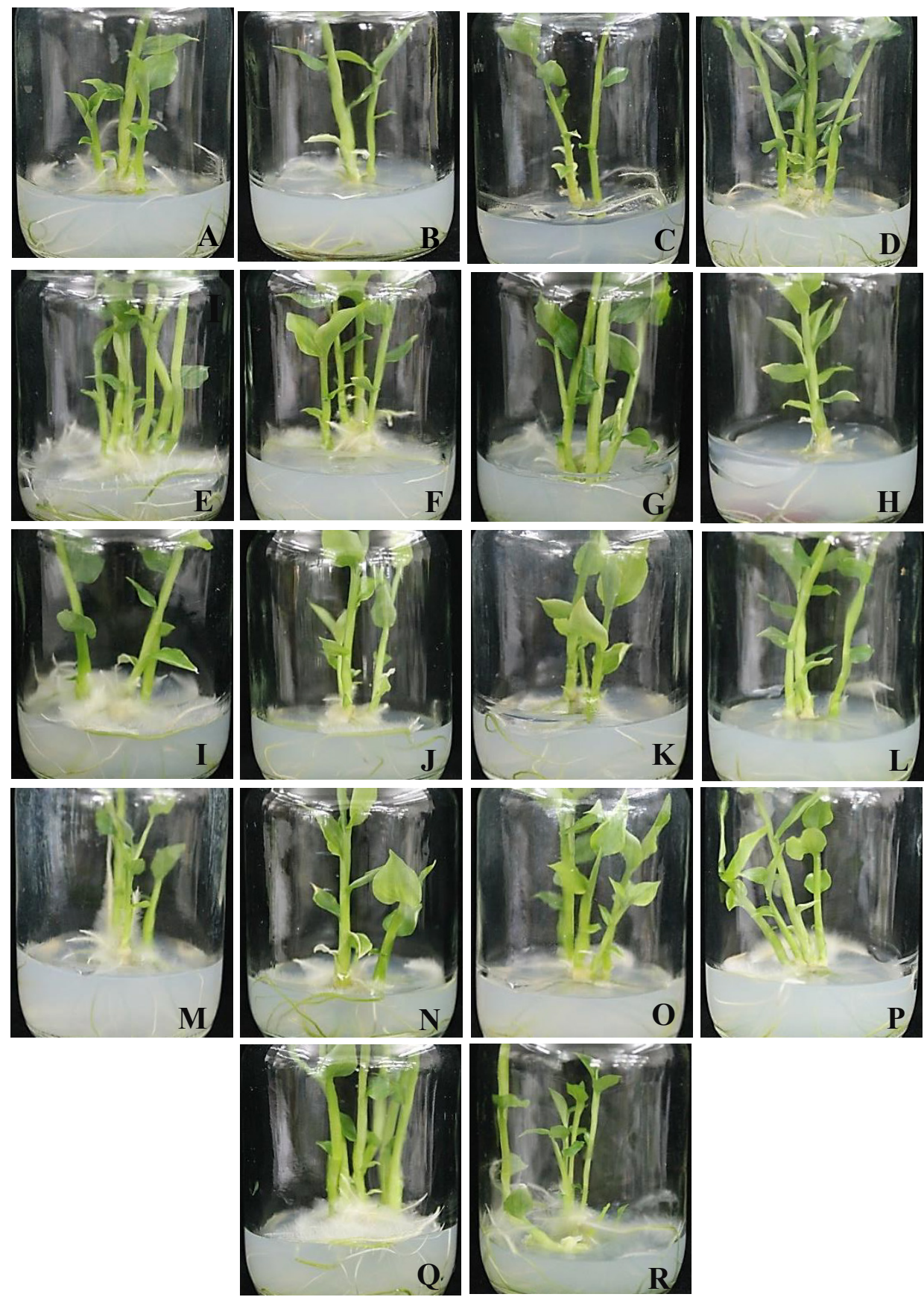

Figure 4 Callus induction and shoot and root formation of G. schomburgkii Hook. f. after 8 weeks of culture (A) free hormone (B) BA $0.5 \mathrm{mg} / \mathrm{l}$ (C) BA $1 \mathrm{mg} / \mathrm{l}$ (D) BA $2 \mathrm{mg} / \mathrm{l}$ (E) BA $3 \mathrm{mg} / \mathrm{l}$ (F) BA $4 \mathrm{mg} / \mathrm{l}$ (G) NAA $0.5 \mathrm{mg} / 1+\mathrm{BA} 0 \mathrm{mg} / \mathrm{l}$ (H) NAA $0.5 \mathrm{mg} / 1+\mathrm{BA} 1 \mathrm{mg} / 1$ (I) NAA $0.5 \mathrm{mg} / \mathrm{l}+\mathrm{BA} 2 \mathrm{mg} / \mathrm{l}$ (J) NAA $0.5 \mathrm{mg} / \mathrm{l}+\mathrm{BA} 3 \mathrm{mg} / \mathrm{l}$ (K) NAA $0.5 \mathrm{mg} / \mathrm{l}+\mathrm{BA} 4 \mathrm{mg} / \mathrm{l}$ (L) NAA $1 \mathrm{mg} / \mathrm{l}+\mathrm{BA} 0 \mathrm{mg} / \mathrm{l}$ (M) NAA $1 \mathrm{mg} / 1+$ BA $0.5 \mathrm{mg} / \mathrm{l}(\mathrm{N}) \mathrm{NAA} 1 \mathrm{mg} / \mathrm{l}+\mathrm{BA} 0.5 \mathrm{mg} / \mathrm{l}(\mathrm{O}) \mathrm{NAA} 1 \mathrm{mg} / \mathrm{l}+\mathrm{BA} 1 \mathrm{mg} / \mathrm{l}(\mathrm{P}) \mathrm{NAA} 1 \mathrm{mg} / \mathrm{l}+\mathrm{BA} 2 \mathrm{mg} / \mathrm{l}$ (Q) NAA $1 \mathrm{mg} / \mathrm{l}+\mathrm{BA} 3 \mathrm{mg} / \mathrm{l}$ (R) NAA $1 \mathrm{mg} / \mathrm{l}+\mathrm{BA} 4 \mathrm{mg} / \mathrm{l}$. 
http://wjst.wu.ac.th

Plantlets (10 cm height) with 5 to 6 leaves and well-developed root systems were removed and transferred to pots containing soil, sand, burned rice husk, soil:sand (1:1), soil:burned rice husk (1:1) and sand:burned rice husk (1:1), sand:burned rice husk (1:1) and soil:sand:burned rice husk (1:1:1) without a hardening process for 8 weeks under greenhouse conditions at the Department of Biology, Faculty of Science, Mahasarakham University, Mahasarakham, Thailand. The highest percentage of surviving plantlets $(80 \%)$, average number of leaves per shoot (21.62), and average shoot length $(15.00 \mathrm{~cm})$ were obtained from plantlets of G. schomburgkii Hook. f. transplanted to sand (Table 4 and Figure 5). These results are different from other authors, who successfully grew in vitro regenerated plants of the ginger family in potting mixtures containing soils. Our results are in agreement with Pimmuen et al. [5], who found that combinations of sand:soil (1:1) and sand:burned rice husk (1:1) were the best acclimatization medium for Globba marantina L., with a survival percentage of $100 \%$. When comparing them with the mother plant, there were no observable differences in the growth characteristics or morphology of the regenerated plants.

Table 4 Effect of potting media on plantlet performance of G. schomburgkii Hook. f. after 8 weeks of acclimatization.

\begin{tabular}{lccc}
\hline Potting medium & $\begin{array}{c}\text { Percentage of } \\
\text { surviving } \\
\text { plantlets }\end{array}$ & $\begin{array}{c}\text { Average no. of } \\
\text { leaves/shoot } \\
\text { mean } \pm \text { SE }\end{array}$ & $\begin{array}{c}\text { Average shoot } \\
\text { length (cm) } \\
\text { mean } \pm \text { SE }\end{array}$ \\
\hline Soil & 73 & $14.98 \pm 0.85^{\mathrm{d}}$ & $10.00 \pm 0.40^{\mathrm{b}}$ \\
Sand & 80 & $21.62 \pm 1.39^{\mathrm{a}}$ & $15.00 \pm 0.75^{\mathrm{a}}$ \\
Burned rice husk & 60 & $17.70 \pm 0.49^{\mathrm{c}}$ & $11.00 \pm 0.44^{\mathrm{b}}$ \\
Soil:Sand & 66 & $21.96 \pm 1.08^{\mathrm{a}}$ & $11.40 \pm 0.47^{\mathrm{b}}$ \\
Soil:Burned rice husk & 73 & $19.56 \pm 0.44^{\mathrm{ab}}$ & $9.90 \pm 0.39^{\mathrm{b}}$ \\
Sand:Burned rice husk & 73 & $19.95 \pm 0.84^{\mathrm{ab}}$ & $10.09 \pm 0.39^{\mathrm{b}}$ \\
Soil:Sand:Burned rice husk & 60 & $12.00 \pm 0.00^{\mathrm{d}}$ & $9.00 \pm 0.00^{\mathrm{b}}$ \\
\hline
\end{tabular}

*Means followed by the same letters within each column are not significantly different at $p \leq 0.05$, according to DMRT.
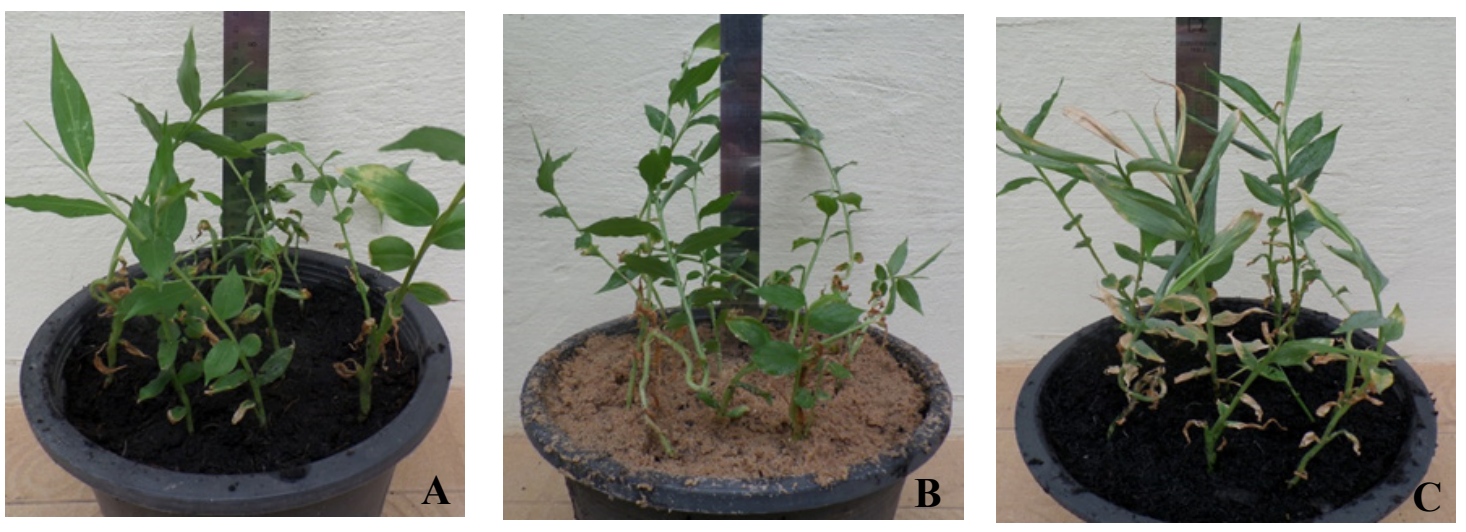

Figure 5 Acclimatized plantlets 8 weeks after transfer to a pot containing soil (A), sand (B), and burned rice husk (C). 
http://wjst.wu.ac.th

\section{Conclusions}

The long divided bulbils of G. schomburgkii Hook. f. showed a better percentage of plant regeneration than the undivided bulbils. Callus formation was found on the MS medium with TDZ, BA alone, or NAA plus BA added. Shoot multiplication of G. schomburgkii Hook. f. can be obtained using $0.1-2 \mathrm{mg} / 1 \mathrm{TDZ}$. Root formation was significantly better when NAA and BA were added to the media (MS). In vitro regenerated plantlets of G. schomburgkii Hook. f. that were planted in sand had a survival rate of $80 \%$. This study presents the first report of callus induction, shoot and root formation, and transplantation of G. schomburgkii Hook. f., which is an attractive ornamental plant from Thailand. This will provide a foundation for propagating plants on a large scale and for genetic manipulation.

\section{Acknowledgements}

Financial support for this work came from Mahasarakham University. Warm thanks to the Biology Department (Faculty of Science) Mahasarakham University, for their facilities and support during this study. Also thanks to Dr. Jolyon Dodgson for language editing and suggestions to improve the manuscript.

\section{References}

[1] K Larsen and SS Larsen. Gingers of Thailand. Queen Sirikit Botanic Garden, Chiang Mai, Thailand 2006.

[2] PE Kho, HB Sani, PC Boyce and SL Sim. In vitro propagation of Globba brachyanthera K. Schum. Asia-Pacific J. Mol. Biol. Biotechnol. 2010; 18, 119-22.

[3] N Chanchula, A Jala and T Taychasinpitak. Break dormancy by trimming immature Globba spp. Int. Trans. J. Eng. Manag. Sci. Tech. 2013; 4, 171-8.

[4] A Jala, N Chanchula and T Taychasinpitak. Multiplication new shoots from embryo culture on Globba spp. Int. Trans. J. Eng. Manag. Sci. Tech. 2013; 4, 207-14.

[5] P Pimmuen, P Saensouk and S Saensouk. In vitro propagation of Globba marantina L (in Thai). KKU. Res. J. 2014; 19, 596-605.

[6] TS Swapna, M Binitha and TS Manju. In vitro multiplication in Kaempferia galanga L. Appl. Biochem. Biotechnol. 2003; 118, 233-41.

[7] K Samsudeen, KN Babu, M Divakaran and PN Ravindran. Plant regeneration from anther derived callus cultures of Ginger (Zingiber officinale Rosc.). J. Hortic. Sci. Biotechnol. 2000; 75, 447-50.

[8] P Saensouk. Callus induction and plant regeneration from leaf explants Cornukaempferia aurantiflora Mood \& Larsen. Pak. J. Bot. 2011; 43, 2415-8.

[9] S Prakash, R Elangomathavan, S Seshadri, K Kathiravan and S Ignacimuthu. Efficient regeneration of Curcuma amada Roxb. plantlets from rhizome and leaf sheath explant. Plant Cell. Tiss. Organ. Cult. 2004; 78, 159-65.

[10] RD Illg and RT Faria. Micropropagation of Alpinia purpurata from inflorescence buds. Plan Cell. Tiss. Organ. Cult. 1995; 40, 183-5.

[11] S Prathanturarug, D Angsumalee, N Pongsiri, S Suwacharangoon and $\mathrm{T}$ Jenjittikul. In vitro propagation of Zingiber petiolatum (Holttum) I. Theilade, a rare zingiberaceous plant from Thailand. In Vitro Cell. Dev. Biol. Plant 2004; 40, 317-20.

[12] T Murashige and F Skoog. A revised medium for rapid growth and bioassays with tobacco tissue cultures. Physiol Plant 192; 15, 473-97.

[13] YH Chong, MM Khalafalla, A Bhatt and LK Chan. The effects of culture systems and explant incision on in vitro propagation of Curcuma zedoaria Roscoe. Pertanika. J. Trop. Agric. Sci. 2012; 35, 863-74.

[14] P Srirat, S Sirisansaneeyakul, P Parakulsuksatid, S Prammanee and W Vanichsriratana. In vitro propagation of Curcuma longa L. from rhizome bud explant. In: Proceedings of the $3^{\text {rd }}$ International Conference on Fermentation Technology for Value Added Agricultural Products. Thailand, 2008, p. 1-5. 
[15] S Lo-apirukk, T Jenjittikul, P Saralamp and S Prathanturarug. Micropropagation of a Thai medicinal plant for women's health, Curcuma comosa Roxb., via shoot and microrhizome inductions. J. Nat. Med. 2012; 66, 265-70.

[16] MN Hamirah, HB Sani, PC Boyce and SL Sim. Micropropagation of red ginger (Zingiber montanum Koenig), a medicinal plant. Asia-Pacific J. Mol. Biol. Biotechnol. 2010; 18, 127-30.

[17] SJ Zhang, N Liu, AW Sheng, GH Ma and GJ Wu. Direct and callus mediated regeneration of Curcuma soloensis Valeton (Zingiberaceae) and ex vitro performance of regenerated plants. Sci. Hortic. 2011; 64, 141-5.

[18] MM Rahman, MN Amin, T Ahamed, A Ahmad, R Ahmed, MB Ahmed and MR Ail. In vitro rapid propagation of Black Thorn (Kaempferia galanga L.): A rare medicinal and aromatic plant of Bangladesh J. Biol. Sci. 2005; 5, 300-4.

[19] KB Kambaska and S Santilata. Effect of plant growth regulator on micropropagation of ginger (Zingiber officinale Rosc.) cv- Suprava and Suruchi. J. Agric. Sci. Tech. 2009; 5, 271-80.

[20] SJ Zhang, N Liu, AW Sheng, GH Ma and GJ Wu. In vitro plant regeneration from organogenic callus of Curcuma kwangsiensis Lindl. (Zingiberaceae). Plant Growth Regul. 2011; 64, 141-5. 